\title{
INNOVATIVE MEANS OF FORMATION OF THE CONCEPT OF ASSESSMENT OF SUSTAINABLE DEVELOPMENT IN THE SYSTEM: ENTERPRISE - INDUSTRY - REGION - STATE
}

\author{
Yelyzaveta SYNETSKA, Slovak University of Agriculture in Nitra, Trieda Andreja Hlinku 2, 94976 Nitra, Slovak Republic, \\ xsynetska@uniag.sk (corresponding author) \\ Daniela HUPKOVÁ, Slovak University of Agriculture in Nitra, Trieda Andreja Hlinku 2, 94976 Nitra, Slovak Republic, \\ daniela.hupkova@uniag.sk \\ Ludmila DOBOŠOVÁ, Slovak University of Agriculture in Nitra, Trieda Andreja Hlinku 2, 94976 Nitra, Slovak Republic, \\ ludmila.dobosova@uniag.sk \\ Erika LOUČANOVÁ, Technical University in Zvolen, Ul. T. G. Masaryka 24, 96001 Zvolen, Slovak Republic, \\ loucanova@tuzvo.sk \\ The subject of the article is the theoretical and applied aspects of assessing the level of achieving sustainable development of \\ the enterprise. \\ The aim of the research is to use innovative means to develop the concept of assessing the level of achievement of sustainable \\ development in the system: enterprise-industry-region-state. \\ During the study, groups of external and internal stakeholders were identified from the position of 3 levels. There is a significant \\ inconsistency of motives of stakeholders in the implementation of the concept of sustainable development at the enterprise le vel \\ and a diverse vision of the essence and meaning of the term sustainable development of the enterprise. This necessitated the \\ formulation of the concept of assessing sustainable development in the system: enterprise - industry - region - state in terms of \\ external and internal sustainability of development. \\ The obtained results describe a system of indicators of the level of sustainable development in terms of its "usefulness" for the \\ regional and national economy and can be used to develop and implement measures to ensure sustainable development at the \\ individual enterprise, region, industry and state.
}

Keywords: sustainable development, concept, evaluation, system, enterprise, branch, region, state, efficiency, indicators.

\section{INTRODUCTION}

In 1992, at the UN Conference in Rio de Janeiro, representatives of 179 countries recognized that the modern world is in an unstable state. Indeed, the fight against poverty, hunger, lack of opportunities for proper education, and the destruction of ecological systems are only deteriorating and negatively affecting the future of society. At the same time, Sustainable Development defines a model of social development in which the needs of the current generation of people are met without depriving future generations of such an opportunity at the expense of environmental means.

It should be mentioned that Ukraine made the choice in favour of the European democratic model, which is being implemented in the country with the support of the EU member states (Rovný et al, 2021). All these and other circumstances determined the urgency and timeliness of the problem. The concept of sustainable development is now one of the most discussed areas of civilization, research, political aspirations. At the same time, the system for assessing the level of achievement of sustainable development by individual domestic enterprises in accordance with European standards based on clearly defined indicators and indicators has not yet been formed, which has determined the purpose and objectives of that scientific research.

The vast majority of research on the implementation of the concept of Sustainable Development focuses on macroeconomic theory and covered in works of scientists such as: Jeffrey Sachts, Herman Daly, Marco Rieckmann, William McDonough, O. Alimov, I. Dragan, O. Grebenuk, I. Mykytenko, I. Lytsura, M. Averkyna. Problematic issues of evaluating the effectiveness of certain processes of economic activity of enterprises, which allows for sustainable development, have been studied by scientists in various aspects of the issue: increasing the efficiency of the territorial unit, ensuring its sustainable development B. Andrushkiv. Assessment of man-made losses in the structure of the mechanism of sustainable development of economic systems - R. Hinz, R. Huefner, F. Wimmer, M.

Copyright (C) 2021 The Authors. Published by Vytautas Magnus University. This is an open-access article distributed under the terms of the Creative Commons Attribution License (CC BY 4.0), which permits unrestricted use, distribution, and reproduction in any medium, provided the original author and source are credited. 
Byblyk, O. Kyzmin. Research of economic aspects of natural resources management and ensuring sustainable development in the conditions of decentralization of power in Ukraine - M. Khvesyk, S. Lizun. The issue of assessing the level of sustainable development of enterprises is covered in the works of Zubova O., Teleshevska S .

The study of the peculiarities of the analysis of the level of sustainable development at the enterprise level by such scientists as Jurdis Staniskis and Valdas Abrasikauskas, Gordon Mitchell, Alison Warhurst, and others is quite thorough.

The purpose of the research is to use innovative means of forming the concept of assessing the level of sustainable development in the system: enterprise - industry - region - state.

\section{METHODOLOGY}

In order to achieve the objective in this article were used general scientific and special research methods, in particular: analytical and logical generalizations, system-structural and comparative analysis.

The theoretical and methodological basis of the research is the fundamental theoretical provisions of modern economic theory and management theory, a system-integrated approach to the consideration of the concept of Sustainable Enterprise Development. The information base includes scientific works of scientists on the problems of assessing the level of Sustainable Development at various levels.

\section{RESULTS}

Economic entities (enterprises) in accordance with European requirements are the main factor in the socioeconomic development of both the region and the industry and the national economy as a whole, as they provide employment, production of consumer goods, development of knowledge and skills of society.

In general, we propose to interpret the sustainable development of the enterprise in terms of a systemintegrated approach as a process of continuous change, in which resources are used, including educational components, investments, scientific and technological development, innovation, staff development and institutional changes are consistent and aimed at increasing the level of efficiency of the current activity of the enterprise, meeting its needs and achieving strategic goals in accordance with the environment. As lack of financial control is often a fast way to business failure, owners and managers often wonder how to improve the returns they are getting from their companies. Profitability analysis, revealing the factors affecting profitability, becomes a very useful tool providing guidance to managers in their short-term, as well as strategic decision-making process (Ladvenicová et al, 2019).The logic of this interpretation is expressed in the comprehensive benefit for different stakeholders, which is given in the matrix of coordination of interests and motives of stakeholders, in the implementation of the concept of sustainable development at the enterprise level (Tab. 1). Sometimes they are called interest groups or groups of influence, which we propose to consider from the standpoint of 3 levels, in particular:

- for the company - meeting its needs, i.e. making a profit and improving the image in a competitive market, increasing productivity, optimizing energy consumption, reducing waste, support from local governments, access to foreign markets;

- for the regional and municipal economy - receiving budget revenues in the form of paying taxes by responsible economic entities, strengthening cooperation with government officials of other countries in implementing new regional development programs, solving problems with local employment, reducing pollution by solid industrial and household waste;

- for the national economy - practical implementation of the concept of sustainable development, which is manifested in reducing the negative impact on the environment and improving the overall level of environmental and man-made safety in the country.

The table shows the agreement of expectations of different stakeholders, in particular, it is clear that in terms of economic efficiency, business owners and their partners expect additional benefits in the form of increased profits, i.e., cash "infusions" into the company from the concept of sustainable development.

It is quite interesting to reconcile interests in ensuring social justice: owners, investors, creditors, and partners hope to improve the company's image as socially responsible; employees and top managers expect a fair reward for professionalism, competence, and representatives of local government and the state level pursue the main goal of increasing employment. From this we can conclude that there is a significant discrepancy of the motives of stakeholders in the realisation of sustainable development at the enterprise level in the implementation of social policy.

We believe that the motives of stakeholders to ensure environmental safety in general are divided into two areas:

- improvement of the state of the environment and ecologically safe production technology - for external stakeholders;

- improving the company's image as a producer of environmentally friendly products - for internal stakeholders.

The above indicates that each of the stakeholders has their own ideas and motives for sustainable development. Such a diverse vision of the essence and meaning of one term necessitates the formation of sustainable development framework in the system: enterprise - industry - region - state, in terms of external and internal sustainability of development, each of which requires the use of appropriate analytical tools. 
Table 1. Matrix of coordination of interests and motives of stakeholders in the realisation of the sustainable development framework at the business level

\begin{tabular}{|c|c|c|c|c|}
\hline \multirow{2}{*}{\multicolumn{2}{|c|}{ Stakeholder groups }} & \multicolumn{3}{|c|}{ Expected results from the implementation of sustainable development framework at the business level } \\
\hline & & \multirow{2}{*}{$\begin{array}{l}\text { Economic efficiency } \\
2\end{array}$} & \multirow{2}{*}{$\begin{array}{l}\text { Social responsibility } \\
3\end{array}$} & Ecological safety \\
\hline 1 & & & & 4 \\
\hline \multirow{7}{*}{ 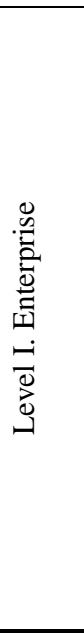 } & \multirow[t]{4}{*}{ Owners } & making a profit & $\begin{array}{l}\text { improving the image of the } \\
\text { company as a socially } \\
\text { responsible }\end{array}$ & $\begin{array}{l}\text { improving the image of the } \\
\text { company as a manufacturer of } \\
\text { environmentally friendly products }\end{array}$ \\
\hline & & $\begin{array}{l}\text { support from local } \\
\text { governments }\end{array}$ & $\begin{array}{l}\text { raising the professional level } \\
\text { and developing the } \\
\text { competencies of employees }\end{array}$ & energy consumption optimization \\
\hline & & \multirow[t]{2}{*}{ access to foreign markets } & growth of labour productivity & \multirow[t]{2}{*}{ waste reduction } \\
\hline & & & $\begin{array}{l}\text { introduction of a system of } \\
\text { employee motivation }\end{array}$ & \\
\hline & \multirow[t]{2}{*}{ Top managers } & \multirow[t]{2}{*}{$\begin{array}{l}\text { reliable assessment of the } \\
\text { effectiveness of enterprise } \\
\text { management }\end{array}$} & $\begin{array}{l}\text { receiving a fair reward for } \\
\text { professionalism, competence, } \\
\text { ability to make effective } \\
\text { management decisions }\end{array}$ & \multirow[t]{2}{*}{$\begin{array}{l}\text { improving the image of the } \\
\text { company as a manufacturer of } \\
\text { environmentally friendly products }\end{array}$} \\
\hline & & & career opportunities & \\
\hline & Employees & $\begin{array}{l}\text { the ability of the enterprise to } \\
\text { pay salaries on time, to make } \\
\text { pension and other payments }\end{array}$ & $\begin{array}{l}\text { receiving a fair reward for } \\
\text { professionalism, competence }\end{array}$ & safe working conditions \\
\hline \multirow{10}{*}{ 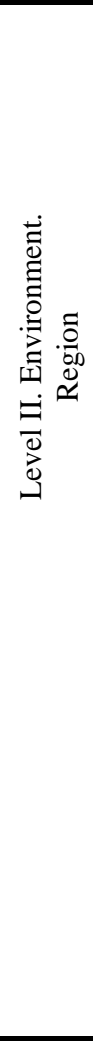 } & Investors & profit guarantee & $\begin{array}{l}\text { improving the image of the } \\
\text { company as a socially } \\
\text { responsible }\end{array}$ & $\begin{array}{l}\text { improving the image of the } \\
\text { company as a manufacturer of } \\
\text { environmentally friendly products }\end{array}$ \\
\hline & Lenders & guarantee of loan repayments & $\begin{array}{l}\text { improving the image of the } \\
\text { company as a socially } \\
\text { responsible }\end{array}$ & $\begin{array}{l}\text { improving the image of the } \\
\text { company as a socially responsible }\end{array}$ \\
\hline & \multirow[t]{2}{*}{$\begin{array}{l}\text { Consumers } \\
\text { (customers) }\end{array}$} & $\begin{array}{l}\text { stability of deliveries as a } \\
\text { consequence of financial } \\
\text { respectability of the } \\
\text { enterprise }\end{array}$ & \multirow[t]{2}{*}{$\begin{array}{l}\text { the presence of a system of } \\
\text { loyalty to consumers }\end{array}$} & \multirow[t]{2}{*}{ environmentally friendly products } \\
\hline & & $\begin{array}{l}\text { availability of a system of } \\
\text { discounts }\end{array}$ & & \\
\hline & \multirow[t]{3}{*}{ Partners } & making a profit & \multirow{3}{*}{$\begin{array}{l}\text { improving the image of the } \\
\text { company as a socially } \\
\text { responsible }\end{array}$} & \multirow{3}{*}{$\begin{array}{l}\text { improving the image of the } \\
\text { company as a manufacturer of } \\
\text { environmentally friendly products }\end{array}$} \\
\hline & & $\begin{array}{l}\text { support from local } \\
\text { governments }\end{array}$ & & \\
\hline & & access to foreign markets & & \\
\hline & Suppliers & $\begin{array}{l}\text { timely payment for the } \\
\text { supply of materials and } \\
\text { resources }\end{array}$ & $\begin{array}{l}\text { availability of a system of } \\
\text { loyalty to suppliers }\end{array}$ & $\begin{array}{l}\text { improving the image of the } \\
\text { company as a manufacturer of } \\
\text { environmentally friendly products }\end{array}$ \\
\hline & \multirow[t]{2}{*}{$\begin{array}{l}\text { Representatives } \\
\text { of local } \\
\text { governments }\end{array}$} & $\begin{array}{l}\text { receiving of funds in the } \\
\text { budget in the form of taxes }\end{array}$ & $\begin{array}{l}\text { employment of the local } \\
\text { population }\end{array}$ & $\begin{array}{l}\text { reduction of pollution by solid } \\
\text { industrial and urban waste, toxic } \\
\text { substances and discharges into } \\
\text { water }\end{array}$ \\
\hline & & $\begin{array}{l}\text { entrenchment collaboration } \\
\text { with government officials in } \\
\text { other countries on the } \\
\text { completion of new regional } \\
\text { development programs }\end{array}$ & $\begin{array}{l}\text { directing funds to the social } \\
\text { needs of the local population }\end{array}$ & $\begin{array}{l}\text { environmentally friendly } \\
\text { production technology }\end{array}$ \\
\hline \multirow{7}{*}{ 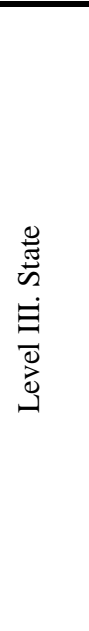 } & \multirow[t]{2}{*}{$\begin{array}{l}\text { Public and state } \\
\text { organizations }\end{array}$} & \multirow{2}{*}{$\begin{array}{l}\text { the well-being of the } \\
\text { country's economic } \\
\text { infrastructure depends on the } \\
\text { successful operation of the } \\
\text { enterprise }\end{array}$} & & $\begin{array}{l}\text { reduction of pollution by solid } \\
\text { industrial and household waste, } \\
\text { toxic substances and discharges } \\
\text { into water bodies }\end{array}$ \\
\hline & & & & $\begin{array}{l}\text { environmentally friendly } \\
\text { production technology }\end{array}$ \\
\hline & \multirow{3}{*}{$\begin{array}{l}\text { Representatives } \\
\text { of the State } \\
\text { Government }\end{array}$} & \multirow{3}{*}{$\begin{array}{l}\text { growth of the national } \\
\text { economy }\end{array}$} & reducing unemployment & rational use of resources \\
\hline & & & $\begin{array}{l}\text { raising the prestige of higher } \\
\text { professional education and } \\
\text { scientific activity }\end{array}$ & $\begin{array}{l}\text { reduction of pollution by solid } \\
\text { industrial and household waste, } \\
\text { toxic substances and discharges } \\
\text { into water bodies }\end{array}$ \\
\hline & & & & $\begin{array}{l}\text { improving the country's image as } \\
\text { an active participant in the } \\
\text { implementation of the "Agenda for } \\
\text { the XXI century" }\end{array}$ \\
\hline & \multirow{2}{*}{$\begin{array}{l}\text { Society as a } \\
\text { whole }\end{array}$} & \multirow{2}{*}{$\begin{array}{l}\text { growth of the national } \\
\text { economy }\end{array}$} & increasing employment & \multirow[t]{2}{*}{ improving the environment } \\
\hline & & & increase welfare & \\
\hline
\end{tabular}


Under the concept of external stability we propose to understand the conflict-free interaction of the enterprise with the external environment and the level of effectiveness of such an enterprise for local governments, society as a whole. Internal stability characterizes the proportionality and balance of all business processes of the enterprise, providing positive dynamics of the main financial and technical and economic indicators of its activities.

Assessing the external stability of the enterprise is used to study its "usefulness" in terms of region or country as a whole. To do this, it is necessary to take as a basis a set of indicators that would allow not only to assess the level of sustainable development of an individual enterprise, but also to compare it with other enterprises within the same industry.

Sustainable development indicators point to spots where the links between the economy, society and the environment are weak. Analysis and evaluation of sustainable development should be based on a system-integrated approach, i.e. the identification of multifactor indicators that reflect the relationship between economic, social and environmental components (table 2).

Table 2. System of indicators for assessing the external stability of the enterprise

\begin{tabular}{|c|c|c|}
\hline \multirow{2}{*}{$\begin{array}{l}\text { Components of sustainable } \\
\text { development of the enterprise }\end{array}$} & \multicolumn{2}{|c|}{ Quantitative indicators of the external stability of the enterprise } \\
\hline & absolute & relative \\
\hline \multirow[t]{6}{*}{ 1. Economic efficiency } & the sum of net profit/loss & market share \\
\hline & the amount of taxes paid & productivity \\
\hline & $\begin{array}{l}\text { amount of attracted investments (financial, } \\
\text { property) }\end{array}$ & share of research costs \\
\hline & $\begin{array}{l}\text { the amount of subsidies, tax benefits, loans } \\
\text { allocated to the company }\end{array}$ & $\begin{array}{l}\text { market share compared to competitors or share of } \\
\text { new projects in the industry }\end{array}$ \\
\hline & \multirow[t]{2}{*}{ the amount of financial assistance } & level of product quality \\
\hline & & resource efficiency \\
\hline \multirow{7}{*}{$\begin{array}{l}\text { 2. Social justice (regulatory } \\
\text { content) }\end{array}$} & number of employees & level of safety and labor protection at work \\
\hline & $\begin{array}{l}\text { the size of the average monthly salary of full- } \\
\text { time employees }\end{array}$ & $\begin{array}{l}\text { the share of full-time employees with higher } \\
\text { education }\end{array}$ \\
\hline & $\begin{array}{l}\text { the amount of deductions for social security } \\
\text { of employees }\end{array}$ & $\begin{array}{l}\text { the ratio of the average wage of employees and the } \\
\text { minimum wage }\end{array}$ \\
\hline & $\begin{array}{l}\text { the number of conflict situations at the } \\
\text { enterprise }\end{array}$ & $\begin{array}{l}\text { the ratio of the average wage of employees with } \\
\text { higher education and the minimum wage }\end{array}$ \\
\hline & $\begin{array}{l}\text { indicators of occupational injuries and } \\
\text { occupational diseases }\end{array}$ & $\begin{array}{l}\text { the share of employees who have completed the } \\
\text { certification trainings }\end{array}$ \\
\hline & number of absences of working days & staff turnover level \\
\hline & $\begin{array}{l}\text { the amount of funds aimed at improving the } \\
\text { skills of employees }\end{array}$ & share of days off and vacations \\
\hline \multirow[t]{7}{*}{$\begin{array}{lc}\text { 3. } & \text { Environmental } \\
\text { (educational content) } & \end{array}$} & $\begin{array}{l}\text { amount of solid household and industrial } \\
\text { waste }\end{array}$ & the share of reused materials and resources \\
\hline & the amount of emissions into water & share of hazardous materials \\
\hline & the amount of greenhouse gas emissions & share of hazardous waste \\
\hline & the amount of electricity consumed & the share of packaging waste \\
\hline & the amount of environmental tax paid & $\begin{array}{l}\text { share of investments in environmental pollution } \\
\text { prevention measures }\end{array}$ \\
\hline & $\begin{array}{l}\text { the amount of resources spent on production } \\
\text { and packaging } \\
\text { products divided into: spent non-renewable } \\
\text { resources; spent renewable resources }\end{array}$ & \\
\hline & $\begin{array}{l}\text { the number of complaints about the negative } \\
\text { impact on the environment, filed, processed } \\
\text { through official mechanisms for their } \\
\text { submission }\end{array}$ & \\
\hline
\end{tabular}

Compiled by the author based on Averkyna et al. (2014); Bublyk and Kuzmin (2014); Global Reporting... (2015); National Round... (2001)

In order to assess detailed level of sustainable development of the enterprise, in addition to quantitative indicators, qualitative indicators should be taken into account. Qualitative indicators of economic efficiency can be the following:

- the ability to change the production schedule when the marketing plan is changing;

- risk or opportunity management methods used in the enterprise;

- the level and effectiveness of the use of benefits, tax credits, subsidies, awards, financial incentives;

- level of impact on the local population and economy.

The group of qualitative indicators of the social component of sustainable development of the enterprise is formed by such indicators: the level of the system of employees' professional development, material and intangible incentives for employees, protection of employees' rights, labor protection; management for suppliers and supply chains, organizational structure and responsibility for overseeing and implementing social policy; level of adherence to ethical standards, transparency, respect for human rights and job satisfaction.

Qualitative indicators of environmental safety should include a system of environmental management, which contains a formalized structure of interrelated procedures - inspections, reports, plans and actions (Global Reporting..., 2015), which are implemented at the enterprise level in order to promote the goals of environmental policy and 
environmental labeling, which is a means of attracting the attention of environmentally conscious buyers and "capture" market share.

\section{CONCLUSIONS AND PROSPECTS FOR FURTHER EXPLORATIONS}

Summing up the results of the study, we believe that in order for the development of the national economy in general and each enterprise in particular to be sustainable in the long run, it must undergo radical changes, which requires constant monitoring and control. Therefore, the need to build a system of indicators of sustainable development of the enterprise and their analysis is due to the degree of influence of the enterprise or its intentions in the future to improve or degrade economic, environmental, and social conditions, development processes and trends at local, regional, and global levels.

In general, indicators of sustainable development are grouped according to their functional purpose:

1. The economic component of sustainable development reflects the analysis of the impact of the enterprise on the economic condition of stakeholders and on economic systems at the local, regional, and global levels. Thus, the data in this category illustrate the movement of capital between different stakeholders.

2. Data on the ecological component of sustainable development characterize the impact of the enterprise on the systems of living and inanimate nature, i.e., land, air, water, and ecosystems. The environmental category includes impacts related to the resources consumed and the waste generated (e.g., emissions, discharges, and wastes), as well as compliance with environmental legislation and environmental costs.

3. Data on the social component of sustainable development characterize the impact of regulatory and legal support on the organization of social systems within which it operates.

Along with the main indicators that characterize the level of achievement of sustainable development of the enterprise in terms of its "usefulness" for local, regional and national development, it is necessary to analyze qualitative indicators for each component of sustainable development in particular.

In order to better understand the nature and features of assessing the level of sustainable development, further research requires the development of a system-integrated methodological approach to assessing its level on the basis of business indicators.

Acknowledgement. This paper was supported by the Ministry of Education, Science, Research and Sport of the Slovak Republic under project VEGA no. 1/0808/21

\section{REFERENCES}

1. Alymov, O. M., Mikitenko, V. V., Lytsur, I. M., Dragan, I. V., Khudoliy, V. Y., Demeshok, O. O., Grebenyuk, A. S. 2013. System and comprehensive evaluation of sustainable development potential of Ukraine. Kyiv: State Institution "Institute of Environmental Economics and Sustainable Development of NAS of Ukraine", $88 \mathrm{p}$.

2. Andrushkiv, B. M. 2014. The Complete regional economic calculation - the way to improve the efficiency of territorial unit and to ensure its sustainable development. Ternopil: Terno-graph.

3. Andrushkiv, B. M., Kyrych, N. B., Malyuta, L. Y, Melnyk, L. M., Pohaydak, O. B. 2016. Ecological vector of modernize the economy and education - European Content of sustainable regional development. Ternopil: Palyanytsya V. A.

4. Arya, B., Horak, S., Bacouel-Jentjens, S. and Ismail, K. 2021. Leading entrepreneurial sustainability initiatives in emerging economies. International Journal of Emerging Markets, Vol. ahead-of-print No. ahead-of-print. https://doi.org/10.1108/IJOEM$\underline{\text { 08-2020-0951 }}$

5. Averkyna, M., Andreeva, N. M., Balgy, M. D., Veklych, A. A. 2014. Sustainable Development - XXI Century. Management, Technologies, Models. Cherkassy: Chabanenko publisher Y. A.

6. Bublyk, M. I., Kuzmin, O. E. 2014. Mechanism of sustainable development of economic systems formation, 1, pp. 109-114.

7. Global Reporting Initiative (GRI). 2015. Guidelines part 1 Reporting Principles and Standard Disclosures. Amsterdam, 97 p.

8. Costanza, R., Alperovitz, G., Daly, H., Farley, J., Franco, C., Jackson, T., Kubiszewski, I., Schor, J., Victor, P. 2017. Building a Sustainable and Desirable Economy-in-Society-in-Nature. In: Shmelev S. (eds) Green Economy Reader. Studies in Ecological Economics, Vol. 6. Springer, Cham. https://doi.org/10.1007/978-3-319-38919-6_16

9. Hvesyk, M. A., Lyzun, S. O. 2015. Economic aspects of natural resource management and sustainable development in the decentralization of power in Ukraine. State institution "Institute of Environmental Economics and Sustainable Development of the National Academy of Sciences of Ukraine.

10. Ilchenko, V., Huleyko, Y. 2012. Analysis of the use of indexes and indicators of sustainable development. Journal of Economy and region, Vol. 6(37), pp. 30-34.

11. Ladvenicová, J., Bajusová, Z., Gurčík, L., Červený, D. 2019. 82 Visegrad Journal on Bioeconomy and Sustainable Development 2/2019 Dupont analysis o arms in V4 countries, Vol. 8, No. 2, 8286. https://doi.org/10.2478/vjbsd-2019-0016

12. Jurgis, K. Staniškis, Valdas Arbačiauskas. 2009. Sustainability Performance Indicators for Industrial Enterprise Management. Environmental Research, Engineering and Management, Vol. 2(48), pp. 42-50.

13. Mitchell, G. 1996. Problems and Fundamentals of Sustainable Development Indicators. Sustainable Development, Vol. 4(1), pp. 1-11. https://doi.org/10.1002/(SICI)1099-1719(199603)4:1\%3C1::AID-SD24\%3E3.0.CO;2-N

14. National Round Table on the Environment and the Economy. 2001. Calculating Eco-Efficiency Indicators. A Workbook for Industry, Canada. https://www.indeco.com/pdfs/nrtee-ecoefficiency-workbook.pdf 
15. Niedlich, S., Bauer, M., Doneliene, M., Jaeger, L., Rieckmann, M., Bormann, I. 2020. Assessment of Sustainability Governance in Higher Education Institutions-A Systemic Tool Using a Governance Equalizer. Sustainability, Vol. 12(5), 1816. https://doi.org/10.3390/su12051816

16. Olsthoorn. 2001. Environmental indicators for business: a review of the literature and standardisation methods. Journal of Cleaner Production, Vol. 9, pp. 453-463. https://doi.org/10.1016/S0959-6526(01)00005-1

17. Hinz, R., Sulser, T.B., Hüfner, R., Mason-D’Croz, D., Dunston, S., Nautiyal, S., Ringler, C., Schüngel, J., Tikhile, P., Wimmer, F. and Schaldach, R. 2020. Agricultural Development and Land Use Change in India: A Scenario Analysis of Trade-Offs Between UN Sustainable Development Goals (SDGs). Earth's Future, Vol. 8, Issue 2. https://doi.org/10.1029/2019EF001287

18. Rovný, P., Moroz, S., Palkovič, J., Horská, E. 2021. Impact of Demographic Structure on Economic Development of Ukrainian Coastal Regions. Sustainability, Vol. 13, No. 4, 1798. https://doi.org/10.3390/su13041798

19. Sachs, J. D., Schmidt-Traub, G., Mazzucato, M., Messner, D., Nakicenovic, N., Rockström, J. 2019. Transformations to achieve the Sustainable Development Goals. Nature Sustainability, Vol. 2, pp. 805-814. https://doi.org/10.1038/s41893-019-0352-9

20. Teleshevska, S. M. 2015. Comprehensive assessment method of sustainable development of enterprises. Journal of Young Scientist, Vol. 6(21), pp. 78-81.

21. UNCTAD. 2004. A Manual for the Preparers and Users of Eco-efficiency Indicators. https://unctad.org/system/files/officialdocument/iteipc20037_en.pdf

22. Warhurst, A. 2002. Sustainability Indicators and Sustainability Performance Management. University of Warwick, UK, No. 43, $129 \mathrm{p}$.

23. Zharova, L. V. 2007. Sustainable development of Ukraine: the inevitability or necessity? Scientific Bulletin of Kyiv Polytechnic Institute, Vol. 4, pp. 4-15.

24. Zubova, A. V. 2011. Methods of assessing and forecasting of agricultural enterprises sustainability. Journal of Kharkov National Technical University of Agriculture: Economics, $112 \mathrm{p}$. 